\title{
The effect of gender and language proficiency on the metaphor use in the writing of TEFL students
}

\author{
Nazila Fattahi* and Musa Nushi
}

\section{*Correspondence:}

nazilafattahi17@gmail.com Shahid Beheshti University, Tehran, Iran

\begin{abstract}
The ubiquitous nature of metaphor in everyday life and its significance in second language learning has triggered plethoric research on the relationship between metaphor and language learning. To contribute to the still growing literature, the current study explore the effect of learner variables, namely gender and proficiency, on metaphor use in TEFL students' writing. To achieve that objective, 27 intermediate and 23 upperintermediate Iranian TEFL students were asked to write on an IELTS Writing Task 2 topic. Fifty essays were analyzed for metaphor use through Metaphor Identification Procedure (Pragglejaz Group in Metaphor Symb 22(1):1-39, 2007) and Vehicle Identification Procedure (Cameron in Metaphor in educational discourse, Continuum, London, 2003). The data analyzed through t-test and multiple regression analysis revealed the advantage of upper-intermediate students over intermediate students concerning metaphor use in their writing. Gender, on the other hand, did not play an influential role in the students' metaphor use. The findings of this research and the implications they might have for the field of English language teaching will be discussed.
\end{abstract}

Keywords: Gender, Language proficiency, L2 writing, Metaphor, Metaphoric competence

\section{Introduction}

Metaphor was traditionally considered as a decorative and fanciful language use and not really pervasive in common speech. Lakoff and Johnson (2003), however, argued against that prevalent view in their book Metaphors We Live By, claiming that metaphor is ubiquitous in everyday life, language, thought, and action. The rationale for using metaphors can be attributed to the fact that it is easier for speakers to think about the abstract concepts in terms of more concrete concepts, probably because understanding abstract concepts are facilitated by concrete ones (Kövecses, 2002). From this perspective, metaphor is no longer looked at as a figure of speech present only in specific genres such as literature but one which is used by native speakers in everyday language effortlessly.

Defining metaphor has always been a challenge for many reasons, two of which have been explicated by Glucksberg (2001). He believes this difficulty stems from the fact that metaphor is used in many different, but related senses and definitions differ to show

(c) The Author(s), 2021. Open Access This article is licensed under a Creative Commons Attribution 4.0 International License, which permits use, sharing, adaptation, distribution and reproduction in any medium or format, as long as you give appropriate credit to the original author(s) and the source, provide a link to the Creative Commons licence, and indicate if changes were made. The images or other third party material in this article are included in the article's Creative Commons licence, unless indicated otherwise in a credit line to the material. If material is not included in the article's Creative Commons licence and your intended use is not permitted by statutory regulation or exceeds the permitted use, you will need to obtain permission directly from the copyright holder. To view a copy of this licence, visit http:// creativecommons.org/licenses/by/4.0/. 
distinctly different theoretical agendas and assumptions. To put it simply, it can be said that metaphor is a type of figurative language, and it is defined in terms of understanding one domain of experience (typically abstract) in terms of another (typically concrete). For instance, in the expression Anger is fire, the abstract target domain (anger) is mapped onto a more concrete source domain (fire). Furthermore, metaphor is both a process and a product, in the sense that the cognitive process conducted to understand a domain is the process aspect of metaphor, while the resulting pattern is the product aspect of it (Kövecses, 2017).

Given the importance of metaphor in the real world context, the necessity of teaching metaphors to second language (L2) learners cannot be ignored. In fact, the ability to use metaphorical language, ideas, and systems conventionally, creatively, strategically, and skillfully, referred to as metaphoric competence (MC) (O'Reilly \& Marsden, 2021a, 2021b), is an indication of L2 fluency. From a psycholinguistic perspective, understanding metaphors occurs when the participants in a conversation give relevant feedback to each other's use of the metaphors. From a discourse analysis perspective, however, the reaction (hence metaphor understanding) is not enough, and what follows from metaphor understanding (a matter of dialogue, engagement in debate) is of importance (Zinken \& Musolff, 2009). It has been suggested that MC of L2 learners is expected to be under the influence of their cognitive and personality-based characteristics (Littlemore \& Low, 2006), such as learners' cognitive style (Hoang, 2019) and personality types (Hashemian, 2018). Indeed, observing learners and gaining more information about their personal differences in the language classroom have always been one of the primary objectives in L2 learning and teaching.

Although there is a rich literature available on L2 learners' metaphor comprehension, there is a need to probe deeper into L2 learners' productive use of the metaphor (Hoang, 2019). To call attention to the significance of productive metaphor use, MacArthur (2010) argues that metaphor is the language learners' most powerful tool to create new meaning from their limited word stock. To enrich the literature on metaphor use by EFL learners, especially Iranian TEFL students, the present study investigates the effect of two learner variables, namely gender and language proficiency, on the metaphor use by Iranian TEFL students in their writing.

\section{Literature review}

\section{Gender and proficiency effects on EFL learning}

In sociolinguistic research, the term 'gender' is used as a social variable, while the term 'sex' is used as a biological one (Baker \& Hengeveld, 2012; Sunderland, 2004). The purpose of this study is not to highlight the distinct effects of such demarcation on EFL teaching; thus, the term gender is used to refer to them both as a whole.

Concerning the role of gender in EFL teaching, early evidence indicates that female learners have advantage over their male counterparts in motivation levels, strategy use, comprehension, and willingness to be exposed to authentic input (Bacon \& Finnemann, 1992). More recently, differences in favor of females have been found in variety and frequency of language learning strategy use, positive attitude towards learning an L2, and more observation of turn-taking rules (Fasold et al., 2014). Some general trends have also been found about the differences between females and males regarding their speech: 
in pronunciation, females often speak slightly more 'correctly' than males; in vocabulary, some words are more used by males than females; and in conversation or speaking behavior, females seem to be more cooperative than interruptive (Baker \& Hengeveld, 2012). Moreover, females speak without stress and pause, while males' speech contains so many interruptions, wrong pronunciation, and grammar (Nasab \& Motlagh, 2017).

Despite the advantage of female learners in some aspects of language learning and use, contradictory evidence has been found, particularly in terms of linguistic performance. Some research suggests female learners outperform males, while other studies indicate the opposite (Fasold et al., 2014). Some authors remain skeptic of the origin and validity of these findings and instead offer other possible explanations that have nothing to do with the gender of the learner as an effective variable per se (e.g., Chastain, 1988; Gu, 2002; Nyikos, 2008). Chastain (1988) states that the belief that female learners are better L2 learners than males is "a carry-over from the past" (p. 128). Whether this assumption is a myth or a realistic reflection of the opinions held by the teachers based on their classroom experiences is unknown to Chastain, but he believes that the fact that the teachers hold such an opinion can play an unnoticed role in L2 classes. Females may perform better simply because both the teachers and the learners expect such a performance. However, he notes that the female learners do seem to receive higher scores in L2 classes.

Psycholinguistic studies suggest that the reason for this discrepancy is due to male and female different language processing strategies. The role of gender in education and how it may affect the L2 learning process have also been recognized (Fasold et al., 2014; Mahmud \& Nur, 2018). For instance, female and male students differ regarding their learning strategies use; female students use cognitive, compensation, and affective strategy more often than males, while male students use memory, metacognitive, and social strategy more often compared with female students (Mahmud \& Nur, 2018). Ross-Feldman's (2007) study about gender differences in L2 learning tasks showed that of the learners' gender influenced language-related episodes (the episodes in which learners interrupt their own conversations in order to clarify questions of grammar, lexical choice, or meaning), with the females tending to play more supportive roles in interactions and attend to the needs of their conversational partners, allowing them more opportunities to interrupt the conversation and ask questions.

The previously mentioned differences seem to be attributed to greater-specific brain activities (Bowden et al., 2005). The fact that the female brain is different from male brain is not surprising, but its implications are quite important for the language pedagogy (Haier \& Jung, 2008). One of the ways in which the study of different brain activities can contribute to EFL teaching is to investigate what changes in brain systems make female and male language acquisition distinct (Shakouri et al., 2016). Coates (2016) cautions that these differences should be handled with skepticism as they might just reflect differences in maturation rates rather than linguistic differences between females and males. Fernández Fontecha (2010) suggest that instead of relying on controversial evidence, it is more fruitful to use neuroimaging methods to arrive at empirical explanations.

Ullman (2005) proposes a reliable model grounded in neurology and psycholinguistics. His declarative/procedural model is a dual system model which sees the language as consisting of two main domains: the mental lexicon, which is related to the declarative 
memory system, and the mental grammar, which is rooted in procedural memory system. This model suggests that females, at least in the initial stages of learning an L2, show an advantage over men. The cause of this advantage is rooted in females' higher lexicaldeclarative memory abilities. At later stages, this advantage will eventually decrease due to L2 practice (Bowden et al., 2005; Ullman, 2005). That said about the issue of gender, now we turn to the issue of $\mathrm{L} 2$ proficiency.

Defining L2 proficiency is part of explaining individual differences in the attainment of an L2 (Hulstijn, 2011). L2 proficiency can be defined as the overall level of development of an L2 learner, meaning how well the learners know a language, or how well they are able to use the language in various communicative situations, in a given modality (Bulté \& Roothooft, 2020; Hulstijn, 2011). A variety of models have been proposed to describe the notion of L2 proficiency. Early models of L2 proficiency consisted of components of linguistic knowledge and four language skills (listening, reading, speaking, and writing), as in the models of Lado (1961), and Carroll (1972). Later on, Canale and Swain (1980) proposed a model of communicative competence consisting of grammatical, sociolinguistic, and strategic competence. This influential model was then extended by Bachman and Palmer (1996), who put forth a three-level hierarchical model, distinguishing organizational language knowledge (grammatical and textual knowledge), pragmatic language knowledge (functional and sociolinguistic knowledge), and a component of strategic competence (metacognitive components and strategies). Lately, L2 proficiency has been identified as a core predictor of learning outcomes, that is, language proficiency determines positive learning outcomes (Yu, 2018).

\section{Gender and proficiency effects on metaphor use in EFL context}

Considering the analysis above, it is expected to see that a learner's characteristics affect their metaphoric competence (Littlemore \& Low, 2006). More specifically, their ability to deal with metaphors is considered to be determined by their proficiency (Hoang, 2015; Galantomos, 2018). Hussey and Katz (2006) have found that males, especially in terms of the slang, produce more metaphors than females. It can be hypothesized that the way in which male and female L2 learners process metaphorical language has similar variations (Galantomos, 2018).

Research demonstrates that there is a relationship between L2 proficiency and the ability to process and produce metaphors. One of the earliest proponents of the idea was Trosborg (1985), who suggested that there is a significant correlation between L2 proficiency and the ability to use and produce metaphors. It has been argued that learners at beginner level will have difficulty with figurative language due to the limited lexical knowledge; learners at intermediate level actually produce figurative language; however, advanced learners, conscious about the acceptability of their interlanguage, are hesitant about producing figurative language (Boers, 2004). In Jin's (2011) study of L2 learners of Chinese and English, one of the key factors affecting metaphoric competence was L2 proficiency. After examining a large body of essays written by Greek and German-speaking learners of English, Littlemore et al. (2014) reported that the MC of these learners was improved from $\mathrm{A} 2$ to $\mathrm{C} 2$, concluding that metaphoric competence is an ongoing and dynamic progress which varies across CEFR levels. In another study, Aleshtar and Dowlatabadi (2014) investigated the relationship between the L2 metaphoric competence and 
L2 proficiency of 60 Iranian undergraduate learners of English. The results showed large correlations between L2 MC and the L2 proficiency. Hoang and Boers (2018) examined the essays written by 257 Vietnamese learners of English through Vehicle Identification Procedure and Metaphor Identification Procedure to probe into the relationship between the quantity of L2 learners' metaphorical language and their language proficiency and the grades given to their essays. Based on their analysis, the quantity of metaphorical language increased systematically by the year levels and the use of metaphorical language correlated positively with the writing performance as assessed by EFL teachers.

\section{Metaphor and L2 writing}

The ability to produce appropriate metaphors in an L2 is no longer a trivial part of linguistic proficiency since without such ability, a language learner cannot adequately express or thoroughly comprehend what a native interlocutor intends to communicate (Saneie Moghadam \& Ghafar Samar, 2020). As writing is a part of productive skills and plays a significant role in every language (Alviana, 2019), to investigate L2 MC, one strand of research has utilized naturalistic data such as L2 learners' writing. Steen et al's (2010) argument regarding the richness of metaphor frequency in academic texts further proves the appropriateness of this genre for metaphor research.

Kapranov (2017) explored the use of metonymy and metaphor in descriptive essays written by 40 EFL university students. By employing both quantitative and qualitative methodologies to analyze the essays, the results revealed that the use of metonymy tends to appear in the writing of intermediate EFL learners. In contrast, both metonymy and metaphor are present in the writing of advanced EFL learners. Hoang (2019) also investigated metaphorical language use L2 learners' writing. Fifteen EFL university learners performed a writing task on a computer and then engaged in a one-on-one interview with the researcher after the writing session. The analysis of the tasks through VIP and the coding of the interviews revealed that to produce metaphors, the participants used different resources and the use of metaphorical language is not more time-consuming than other processes involved in the writing procedure.

\section{Research questions}

To investigate how learner characteristics (i.e., gender and proficiency) affect metaphor use in Iranian TEFL students' writing, the following questions were posed:

1. Does gender significantly affect metaphor use in the written output of Iranian TEFL students?

2. Does language proficiency significantly affect metaphor use in the written output of Iranian TEFL students?

\section{Method}

\section{Participants}

The sample in this study consisted of 50 TEFL students who were doing a four-year B.A. program at a state university in the Iranian capital city of Tehran. They were all first year students and their age ranged from 18 to 22. Of the 50 students, 27 (10 males 
and 17 females) were at the intermediate (B1) level and the remaining 23 (12 males and 11 females) at the upper-intermediate (B2) level, as specified by the Common European Framework of Reference for Languages (CEFR). They were allocated to these levels based on their scores on IELTS writing task. The participants' information is also depicted in Table 1.

\section{Instruments}

Researchers usually use 'naturalistic' data such as unprompted spoken production and written assignments to investigate MC. A characteristic of naturalistic data is that it offers insights into authentic and spontaneous language in use (O'Reilly \& Marsden, 2021a, 2021b). To investigate metaphor use in the writing of the students, the researchers assigned them an IELTS Writing Task 2 to collect the data. IELTS Writing Task 2 was preferred to IELTS Writing Task 1 because the former allows more critical and abstract thinking. Galantomos (2018) argues that (writing) tasks which encourage critical and abstract thinking could provide more chances for metaphor use.

The measurement of the number of metaphors used in the participants' essays was based on the notion of metaphorical density (MD), which has been proposed by Kecskes and Papp (2000). The index of metaphorical density measures the number of metaphorical words/sentences written in a text as a percentage of the total number of sentences written in the same text. For instance, if six sentences appear in a 10-sentence-long text, the MD will be 60 percent. The two most influential tools for metaphor identification in metaphor literature, which are used in this study, are the Metaphor Identification Procedure (MIP) (Pragglejaz Group, 2007) and Vehicle Identification Procedure (VIP) (Cameron, 2003). Both tools try to determine whether the meaning conveyed by a lexical unit in a given context differs from its literal meaning. The MIP considers word as the unit of analysis. For every running word in a text it should be determined, through a dictionary, whether the word is used in its basic sense or in an extended metaphorical sense. VIP takes a more flexible approach using a broader notion of 'vehicles' of metaphors, that is, what non-literal words or phrases are being used to talk about a 'topic. VIP does not require the text to be divided into lexical units, unlike MIP, so there is no restriction on the word limit of a Vehicle term. By using vehicle rather than word as the unit of analysis, one can focus not only on metaphors but also on phrases that are used as wholes; hence, in some cases, whole utterances, sentences, or paragraphs can be underlined as metaphorical.

\section{Data collection procedure}

The participants in this study were asked to write an IELTS Task 2 essay. During the instructions given in English, there was no mention of figurative language. All the guidelines of the IELTS Writing Task 2 were followed, that is, the students were asked

Table 1 The participants' information $(\mathrm{N}=50)$

\begin{tabular}{lllll}
\hline Gender & & Proficiency & \\
& Female & & B1 & B2 \\
\hline 22 & 28 & 27 & 23 \\
\hline
\end{tabular}


to write a minimum 250-word essay to express their opinion on one of the following topics in $40 \mathrm{~min}$ :

1. In many countries, children are engaged in some kind of paid work. Some people regard this as completely wrong, while others consider it as valuable work experience, important for learning and taking responsibility. Discuss both views and give your own opinion.

2. Elaborate on the problems of ELT in Iran and the possible solutions to those problems.

The second topic, although following the IELTS Writing Task 2 structure, deviated from the typical topics seen in IELTS Task 2 because the researchers wished to offer students a topic in line with their major about which they could personally relate to and discuss freely. Ninety essays were collected and handed out to two experienced IELTS writing examiners. Sentences containing global errors were not analyzed. The essays were marked based on the IETLS Writing Task 2 band descriptors. Cohen's kappa coefficient was used to establish the inter-rater reliability, which turned out to be 0.97 . Despite the instructions, some students failed to meet the word count requirement (20 out of 90 submitted essays were under 250 words), leaving the raters with a sample of 70 essays to mark. The IELTS writing task scores were converted to their CEFR scale equivalents to put the participants into two proficiency levels of B1 and B2. The procedure required those essays with scores below 4 and above 6.5 be omitted from the sample. The final corpus consisted of 50 essays, 27 of which were placed in B1 and 23 in B2 proficiency level.

Next, the 50 essays were analyzed for metaphor use. Being familiar with MIP, VIP, and the index of metaphorical density, the two researchers analyzed the collected essays independently. In a session, the problematic sentences were discussed and a Cohen's kappa coefficient of 0.90 was reached.

\section{Results}

Staring with the question of whether gender has an effect on the students' metaphor use, the mean and standard deviation of the two groups of participants, displayed in Table 2, revealed that the male students used more metaphors $(M=76.2, S D=14.4)$ in their writing compared with the female participants $(M=70.7, S D=18.4)$. However, inferential statistics were applied in order to examine whether the difference observed between the two groups of the participants was statistically significant.

Table 2 Means and standard deviations of the male and female students

\begin{tabular}{ccccc}
\hline Gender & N & Mean & Std. deviation & Std. error mean \\
\hline MD & & & & \\
F & 28 & 70.79 & 18.45 & 3.48 \\
M & 22 & 76.27 & 14.46 & 3.08 \\
\hline
\end{tabular}


The independent $\mathrm{t}$-test revealed the difference between the male and female students was of no statistical significance; $t(48)=-1.14, \mathrm{p}>0.05$. That is to say, gender exerted no significant effect on the metaphor use in Iranian TEFL students' writing (Table 3).

Turning to the question of whether language proficiency affects metaphor use in the students' writing, Table 4 depicts that the students at $\mathrm{B} 2$ level $(\mathrm{M}=84.09, \mathrm{SD}=12.7)$ outperformed those at $\mathrm{B} 1(\mathrm{M}=63.93, \mathrm{SD}=14.3)$. Independent $\mathrm{t}$-test also supports this result by showing a significant difference between these two groups; $t(48)=-5.215$, $\mathrm{p}<0.05$. In other words, students at the higher proficiency level used more metaphors in their writing compared with those at the lower level (Table 5).

Finally, a multiple linear regression was carried out to investigate whether gender and proficiency level could significantly affect participants' metaphor use in writing. As

Table 3 Independent samples t-test of the male and female students

\begin{tabular}{|c|c|c|c|c|c|c|c|c|c|}
\hline & \multicolumn{4}{|c|}{$\begin{array}{l}\text { Levene's test for equality } \\
\text { of variances }\end{array}$} & \multicolumn{5}{|c|}{ T-test for equality of means } \\
\hline & \multirow[t]{2}{*}{$\mathbf{F}$} & \multirow[t]{2}{*}{ Sig. } & \multirow[t]{2}{*}{$\mathrm{t}$} & \multirow[t]{2}{*}{ Df } & \multirow[t]{2}{*}{ Sig. (2-tailed) } & \multirow[t]{2}{*}{ Mean difference } & \multirow[t]{2}{*}{$\begin{array}{l}\text { Std. error } \\
\text { difference }\end{array}$} & \multicolumn{2}{|c|}{$\begin{array}{l}95 \% \text { confidence } \\
\text { interval of the } \\
\text { difference }\end{array}$} \\
\hline & & & & & & & & Lower & Upper \\
\hline \multicolumn{10}{|l|}{ MD } \\
\hline $\begin{array}{l}\text { Equal } \\
\text { variances } \\
\text { assumed }\end{array}$ & 2.38 & .129 & -1.14 & 48 & .258 & -5.48 & 4.79 & -15.12 & 4.15 \\
\hline $\begin{array}{l}\text { Equal } \\
\text { variances } \\
\text { not } \\
\text { assumed }\end{array}$ & & & -1.17 & 48.00 & .244 & -5.48 & 4.65 & -14.84 & 3.87 \\
\hline
\end{tabular}

Table 4 Means and standard deviations of the students at B1 and B2 levels

\begin{tabular}{ccccc}
\hline Proficiency & N & Mean & Std. deviation & Std. error mean \\
\hline MD & & & & \\
B1 & 27 & 63.93 & 14.35 & 2.76 \\
B2 & 23 & 84.09 & 12.70 & 2.64 \\
\hline
\end{tabular}

Table 5 Independent samples t-test of the students at B1 and B2 levels

\begin{tabular}{|c|c|c|c|c|c|c|c|c|c|}
\hline & \multicolumn{4}{|c|}{$\begin{array}{l}\text { Levene's test for equality } \\
\text { of variances }\end{array}$} & \multicolumn{5}{|c|}{ t-test for equality of means } \\
\hline & \multirow[t]{2}{*}{$\mathbf{F}$} & \multirow[t]{2}{*}{ Sig. } & \multirow[t]{2}{*}{$\mathbf{t}$} & \multirow[t]{2}{*}{ Df } & \multirow[t]{2}{*}{ Sig. (2-tailed) } & \multirow[t]{2}{*}{ Mean difference } & \multirow[t]{2}{*}{$\begin{array}{l}\text { Std. error } \\
\text { difference }\end{array}$} & \multicolumn{2}{|c|}{$\begin{array}{l}95 \% \text { confidence } \\
\text { interval of the } \\
\text { difference }\end{array}$} \\
\hline & & & & & & & & Lower & Upper \\
\hline \multicolumn{10}{|l|}{ MD } \\
\hline $\begin{array}{l}\text { Equal } \\
\text { variances } \\
\text { assumed }\end{array}$ & .14 & .71 & -5.21 & 48 & .000 & -20.16 & 3.86 & -27.93 & -12.38 \\
\hline $\begin{array}{l}\text { Equal } \\
\text { variances } \\
\text { not } \\
\text { assumed }\end{array}$ & & & -5.26 & 47.918 & .000 & -20.16 & 3.82 & -27.85 & -12.46 \\
\hline
\end{tabular}


displayed in Table $6, \mathrm{R}=0.606$ indicates a strong relationship between gender and proficiency level. However, to see whether this relationship is of significance or not, results of ANOVA were required (Table 7). As the significance value is less than $\mathrm{p}<0.05$, it is evident that the regression model significantly predicts metaphor use, $F(2.47)=13.61$, $p=0.00$. Table 8 indicates the extent to which each individual variable contributes to the model. The results shows that while proficiency level affects metaphor use significantly $(B=19.7, p<0.05)$, gender does not $(B=2.4, p=0.07)$.

\section{Discussion}

The present study aimed at investigating the effect of two individual variables, namely gender and language proficiency, on the use of metaphor in the writing of Iranian TEFL students. The results obtained through independent $\mathrm{t}$-test and linear multiple regression revealed that while proficiency level affected the use of metaphor in writing, gender did not.

Despite the researchers' initial expectations regarding a low metaphoric competence among the Iranian TEFL students, they were surprised to observe that the students were familiar with figurative language and able to produce metaphors in written discourse. Metaphorical density of the students of both proficiency levels ranged from 37 to 100 percent. In order to illustrate the metaphorical density of the writing of our participants, two excerpts are presented here. The metaphors in these excerpts are underlined.

\section{Excerpt 1}

Table 6 Multiple regression analysis to predict the effect of gender and proficiency

\begin{tabular}{lllll}
\hline Model & $\mathbf{R}$ & R square & Adjusted R square & Std. error of the estimate \\
\hline 1 & $.606^{\mathrm{a}}$ & .36 & .34 & 13.71 \\
\hline a Predictors: (constant), value, gender & &
\end{tabular}

Table 7 ANOVA $A^{a}$ results of the predictive power of gender and proficiency

\begin{tabular}{lccccc}
\hline Model & Sum of squares & df & Mean square & F & Sig. \\
\hline 1 & & & & & \\
Regression & 5121.60 & 2 & 2560.80 & 13.61 & $.000^{\mathbf{b}}$ \\
Residual & 8838.40 & 47 & 188.05 & & \\
Total & $13,960.00$ & 49 & & & \\
\hline
\end{tabular}

a Predictors: (constant), value, gender

${ }^{\mathrm{b}}$ Dependent variable: MD

Table 8 Coefficients ${ }^{\mathrm{a}}$ of gender and proficiency

\begin{tabular}{|c|c|c|c|c|c|}
\hline \multirow[t]{2}{*}{ Model } & \multicolumn{2}{|c|}{ Unstandardized coefficients } & \multirow{2}{*}{$\begin{array}{l}\text { Standardized } \\
\text { coefficients } \\
\text { Beta }\end{array}$} & \multirow[t]{2}{*}{$\mathbf{T}$} & \multirow[t]{2}{*}{ Sig. } \\
\hline & B & Std. error & & & \\
\hline \multicolumn{6}{|l|}{1} \\
\hline (Constant) & 40.75 & 7.69 & & 5.29 & .000 \\
\hline Gender & 2.46 & 3.95 & .07 & .62 & .535 \\
\hline Level & 19.78 & 3.93 & .59 & 5.02 & .000 \\
\hline
\end{tabular}

${ }^{a}$ Dependent variable: MD 
Despite increasing demand for teachers and instructor due to mentioned reasons, they have always been underpaid by stakeholders and the authorities. With this in mind, it is obvious why teachers and instructors pay less or no effort on teaching energetically. Even if authorities allocate more time than standard norms for teaching or providing up to date facilities and technology, which is common in well-known private institutes, we cannot observe any proper development in the learner's performance.

\section{Excerpt 2}

To start with, let us investigate the root of having unqualified teachers. As political ties among Iran and countries in charge of running professional and prestigious teacher training courses is not that well-established, so as a result, the very T.T.C courses, say, CELTA, DELTA, are not in Iran. In this regard, teachers here are deprived of such down-to-earth and efficient courses and workshops. To get away from this issue, I think nations need to detach political issues from educational ones, such as EFL/ESL, and let these realms stay away from such politics.

Excerpt 1 is taken from an essay of 300 words; out of 15 sentences in this essay, 13 contained metaphors. Excerpt 2 is from an essay of 259 words and each sentence in this essay contains metaphors (i.e., an MD of 100\%). For detailed information on the essays used in data collection, see the Appendix.

Gender differences did not prove to be a sufficiently robust variable affecting the metaphor use by the Iranian TEFL students in this study. Findings of the previous studies regarding gender differences on figurative language and language learning in general have reported female superiority over men (e.g., Galantomos, 2018; Gu, 2002; Iwaniec, 2019;). However, other studies, similar to ours, found no significant difference between them (e.g., Morris, 1998). One way to explain the contradictory findings is to probe deeper into the characteristics of the participants. In Galantomos's (2018) study of metaphor use in writing, gender differences were observed among private school students, while our participants were drawn from the university context. The findings of the present research are in line with the argument put forward by Khajavy et al. (2020) who believe that gender differences might not be prevalent at the university level. Furthermore, there are researchers who criticize interpretations built upon the traditional general view that gender is always relevant to understanding language learning outcomes. Instead of considering gender as a static personal trait, they view gender as a dynamic social variable, which interacts with and is mediated by various social traits, such as race, ethnicity, sexuality, age, social status and class, educational background, and cultural norms (Norton \& Pavlenko, 2004; Pavlenko \& Piller, 2001). Even Galantomos (2018) admits that gender differences in his study can be interpreted from an alternative view which regards gender to be of a dynamic nature influenced by various relations and social practices, such as gender roles and identity. Moreover, it is worth mentioning that despite the available literature highlighting gender differences in language acquisition, there is a dearth of studies focusing particularly on gender differences in L2 MC. Generalizing the observed gender differences in other areas of language acquisition to L2 MC may not be justified. As Kecskes (2000) points 
out, metaphor goes beyond language and structures human thought processes. Hence more specific research regarding the effect of gender on L2 MC is called for.

Analyzing the essays written by the Iranian TEFL students revealed that the students at B2 level demonstrate a better command of figurative language than their B1 peers. In other words, students with higher L2 proficiency have a better command of figurative language. This finding may be accounted for by the fact that low proficiency learners with limited lexical knowledge also have limited figurative language knowledge while more proficient learners are aware of the pervasive nature of figurative language and its significance in improving their language proficiency.

These results align well with the previous studies indicating a positive relationship between language proficiency and MC. For instance, Littlemore et al. (2014) report that the overall density of metaphor increases from CEFR levels A2 to C2. In Hoang and Boers' (2018) analysis of 257 undergraduate English majors at three different year levels, the proportion of metaphorical language was found to be positively related to the students' year levels. In a similar vein, Galantomos's (2018) small-scale study of the metaphor use of Greek learners demonstrated the superiority of C2 learners over B2 learners. Moreover, Hoang's (2015) investigation of L2 language learners' essays revealed a significant relationship between the learners' metaphorical language and their general language proficiency at different year levels. Nourmohamadi (2010) also found similar results, highlighting the correlation between the learners' overall language proficiency and their ability to comprehend conventional English metaphors.

\section{Conclusion}

The present study set out to shed light on the effect of language proficiency and gender on the metaphor use in the writing of Iranian TEFL students. Concerning language proficiency, the results of this study are in accordance with the general trend of previous studies that have indicated a close relationship between L2 proficiency and the ability to use metaphors, that is, metaphor use increased across the CEFR levels. However, with regard to the role of gender in metaphor use, the findings deviate from the available literature and no significant difference was observed in the use of metaphor by male and female participants.

The findings of this study suggest a number of implications for FL classrooms, teachers, and materials writers. As mentioned before, the ever-present nature of metaphor in everyday language makes it an indispensable part of language proficiency. This is a fact that needs to be highlighted by teachers as learners' awareness of the ubiquities nature of metaphor may motivate them in improving their metaphoric competence. The pervasiveness of figurative language in everyday communication also raises the importance of metaphor instruction in language classrooms. Language learners can benefit from explicit teaching of figurative language from the early stages of their education (Galantomos, 2018; Gutiérrez Pérez, 2018; Liu \& Hsieh, 2020). The CEFR metaphor descriptors for levels A2 to C2 developed by Littlemore et al. (2014) can prove helpful in that regard.

Metaphor instruction can also be beneficial for the depth of learners' vocabulary knowledge. Hoang and Boers (2018) believe that "the mastery of metaphorical language and depth of vocabulary knowledge can be considered two sides of the same coin" (p. 7). Based on their findings, they argue that engaging learners with figurative language and 
mechanisms of meaning extensions improve the kind of vocabulary knowledge which promotes the quality of their writing.

Furthermore, language teaching materials can play an important role in improving metaphoric competence, as they are one of the pillars of any L2 classroom. MacArthur (2010) points out the importance of the resources available for learners for developing their metaphoric competence. Hence, material designers can include more activities with a focus on various aspects of figurative language in L2 textbooks.

Additionally, teachers can be advised to leave behind their preconceived notions regarding gender differences before entering the classroom. Schmenk (2004) postulates that considering language learning as a feminine domain and other traditional notions about the performance of male and female learners in the classroom are particular instances of stereotyping. Teachers must take a critical stance toward generalist statements about male and female learners and be aware of gender stereotyping to be able to focus on individual learners as persons.

It needs to be acknowledged that the present study, like any other study, suffers from some limitations. As the participants of this study are TEFL students, generalizations must be made with caution. The characteristics of these students make the attained results not generalizable to EFL learners. Research comparing these two groups of learners may reveal interesting findings. Besides, the presented data here was collected only form one university in one Iranian city. Future research may expand the setting by collecting data from different universities in different cities in the country or even from other countries. The proficiency levels investigated too were limited to B1 and B2; more CEFER levels may be added for more generalizable results.

\section{Appendix}

Information of the essays at B1 level

\begin{tabular}{llllll}
\hline Writing & Gender & $\begin{array}{l}\text { No. of sentences } \\
\text { containing metaphors }\end{array}$ & $\begin{array}{l}\text { No. of } \\
\text { sentences }\end{array}$ & IELTS Score & MD \% \\
\hline 1 & 10 & 21 & $4 / 5$ & 48 \\
2 & $F$ & 7 & 11 & $4 / 5$ & 63 \\
3 & $F$ & 13 & 4 & 61 \\
4 & $F$ & 20 & 5 & 40 \\
5 & $F$ & 15 & 5 & 60 \\
6 & M & 9 & 16 & $4 / 5$ & 37 \\
7 & $F$ & 15 & 5 & 60 \\
8 & M & 9 & 11 & 5 & 82 \\
9 & F & 9 & 16 & $4 / 5$ & 69 \\
10 & M & 11 & 18 & 5 & 50 \\
11 & $F$ & 9 & 16 & 5 & 56 \\
12 & $F$ & 9 & 12 & 4 & 67 \\
13 & F & 8 & 18 & $4 / 5$ & 44 \\
14 & M & F & 22 & $4 / 5$ & 45 \\
15 & F & 6 & 12 & 4 & 50 \\
16 & F & 12 & 16 & 4 & 75 \\
\hline
\end{tabular}




\begin{tabular}{llllll}
\hline Writing & Gender & $\begin{array}{l}\text { No. of sentences } \\
\text { containing metaphors }\end{array}$ & $\begin{array}{l}\text { No. of } \\
\text { sentences }\end{array}$ & IELTS Score & MD \% \\
\hline 17 & F & 11 & 17 & 5 & 65 \\
18 & F & 13 & 19 & 4 & 68 \\
19 & M & 15 & 17 & 4 & 88 \\
20 & M & 13 & 17 & $4 / 5$ & 76 \\
21 & M & 11 & 12 & $4 / 5$ & 92 \\
22 & F & 11 & 15 & 4 & 73 \\
23 & M & 15 & 19 & $4 / 5$ & 79 \\
24 & M & 9 & 12 & 5 & 75 \\
25 & F & 13 & 21 & $4 / 5$ & 62 \\
26 & M & 14 & 19 & $4 / 5$ & 74 \\
27 & F & 14 & 21 & 4 & 67 \\
\hline
\end{tabular}

\section{Information of the essays at B2 level}

\begin{tabular}{|c|c|c|c|c|c|}
\hline Writing & Gender & $\begin{array}{l}\text { No. of sentences } \\
\text { containing metaphors }\end{array}$ & $\begin{array}{l}\text { No. of } \\
\text { sentences }\end{array}$ & IELTS Score & MD \% \\
\hline 1 & M & 10 & 14 & 6 & 71 \\
\hline 2 & $\mathrm{~F}$ & 14 & 19 & 6 & 74 \\
\hline 3 & $\mathrm{~F}$ & 13 & 15 & 6 & 87 \\
\hline 4 & M & 9 & 12 & $5 / 5$ & 75 \\
\hline 5 & $\mathrm{~F}$ & 13 & 15 & $5 / 5$ & 86 \\
\hline 6 & M & 9 & 13 & 6 & 69 \\
\hline 7 & $\mathrm{~F}$ & 19 & 25 & $5 / 5$ & 76 \\
\hline 8 & M & 10 & 14 & $5 / 5$ & 71 \\
\hline 9 & $\mathrm{~F}$ & 15 & 15 & $5 / 5$ & 100 \\
\hline 10 & M & 13 & 15 & $5 / 5$ & 87 \\
\hline 11 & M & 14 & 16 & $5 / 5$ & 87 \\
\hline 12 & M & 17 & 18 & $5 / 5$ & 94 \\
\hline 13 & $\mathrm{~F}$ & 20 & 21 & $5 / 5$ & 95 \\
\hline 14 & M & 14 & 18 & $5 / 5$ & 78 \\
\hline 15 & $\mathrm{~F}$ & 15 & 20 & $5 / 5$ & 75 \\
\hline 16 & M & 10 & 10 & $6 / 5$ & 100 \\
\hline 17 & M & 13 & 25 & 6 & 52 \\
\hline 18 & $\mathrm{~F}$ & 16 & 16 & $6 / 5$ & 100 \\
\hline 19 & M & 10 & 13 & $5 / 5$ & 77 \\
\hline 20 & $\mathrm{~F}$ & 19 & 21 & $5 / 5$ & 90 \\
\hline 21 & $\mathrm{~F}$ & 18 & 19 & 6 & 95 \\
\hline 22 & $\mathrm{~F}$ & 21 & 22 & $5 / 5$ & 95 \\
\hline 23 & M & 14 & 16 & $6 / 5$ & 100 \\
\hline
\end{tabular}

\section{Abbreviations}

EFL: English as a Foreign Language; L2: Second language; MIP: Metaphor identification procedure; MC: Metaphoric competence; TEFL: Teaching English as a Foreign Language; VIP: Vehicle identification procedure.

Acknowledgements

We would like to express our gratitude to the participants of this study.

Authors' contributions

NF conceived the research idea, designed the study and prepared the data for analysis. MN collected the data, and conducted the data analysis. The two authors interpreted the results and wrote several drafts of the paper. MN commented on the manuscript multiple times and NF revised and edited the manuscript accordingly. NF selected the appropriate journal, formatted the manuscript and did the corresponding with the journal. Both authors read and approved the final manuscript. 


\section{Funding}

There were no sources of funding for the research reported in this manuscript.

Availability of data and materials

The datasets of the study are available from the corresponding author on reasonable request.

\section{Declarations}

\section{Competing interests}

The authors declare that they have no competing interests.

Received: 9 October 2021 Accepted: 14 November 2021

Published online: 18 November 2021

\section{References}

Aleshtar, W. T., \& Dowlatabadi, H. (2014). Metaphoric competence and language proficiency in the same boat. ProcediaSocial and Behavioral Sciences, 98, 1895-1904.

Alviana, V. (2019). The effect of the recipe demonstration technique on students' writing competence in procedural text. Journal of Languages and Language Teaching, 7(2), 128-131.

Bachman, L. F., \& Palmer, A. S. (1996). Language testing in practice. Oxford University Press.

Bacon, S., \& Finnemann, M. D. (1992). Sex differences in self-reported beliefs about foreign-language learning and authentic oral and written input. Language Learning, 42(4), 471-495.

Baker, A. E., \& Hengeveld, K. (2012). Linguistics. Wiley.

Boers, F. (2004). Expanding learners'vocabulary through metaphor awareness: What expansion, what learners, what vocabulary? In M. Achard \& S. Niemeier (Eds.), Cognitive linguistics, second language acquisition, and foreign language teaching (pp. 211-232). Mouton de Gruyter.

Bowden, H. W., Sanz, C., \& Stafford, C. A. (2005). Individual differences: Age, sex, working memory, and prior knowledge. In C. Sanz (Ed.), Mind and context in adult second language acquisition: Methods, theory, and practice (pp. 105-140). Georgetown University Press.

Bulté, B., \& Roothooft, H. (2020). Investigating the interrelationship between rated L2 proficiency and linguistic complexity in L2 speech. System, 91, 102246. https://doi.org/10.1016/j.system.2020.102246

Cameron, L. (2003). Metaphor in educational discourse. Continuum.

Canale, M., \& Swain, M. (1980). Theoretical bases of communicative approaches to second language teaching and testing. Applied Linguistics, 1(1), 1-47.

Carroll, J. B. (1972). Fundamental considerations in testing for English language proficiency of foreign students. In H. B. Allen \& R. N. Campbell (Eds.), Teaching English as a second language: A book of readings (pp. 313-320). McGraw Hill.

Chastain, K. (1988). Developing second-language skills: Theory and practice. Harcourt Brace Jovanovich.

Coates, J. (2016). Women, men and language. A sociolinguistic account of gender differences in language (3rd ed.). Routledge.

Fasold, R. W., \& Connor-Linton, J. (Eds.). (2014). An introduction to language and linguistics. Cambridge University Press.

Fernández Fontecha, A. (2010). Gender and motivation in EFL vocabulary production. In R. M. Jiménez Catalán (Ed.), Gender perspectives on vocabulary in foreign and second languages (pp. 93-116). Palgrave Macmillan.

Galantomos, I. (2018). Gender and proficiency effects on metaphor use among Greek learners. International Journal of Applied Linguistics, 29(1), 61-77.

Glucksberg, S. (2001). Metaphor the central trope. In S. Glucksberg (Ed.), Understanding figurative language: From metaphors to idioms (pp. 3-15). Oxford University.

Gu, Y. (2002). Gender, academic major, and vocabulary learning strategies of Chinese EFL learners. RELC Journal, 33(1), $35-54$.

Gutiérrez Pérez, R. (2018). The development of a metaphoric competence. A didactic proposal of educational innovation. Innovation in Language Learning and Teaching, 13(4), 331-357.

Haier, R. J., \& Jung, R. E. (2008). Brain imaging studies of intelligence and creativity: What is the picture for education. Roeper Review, 30, 171-180.

Hashemian, M. (2018). A study of L2 learners'metaphorical competence and personality types: A case of thinking/feeling vs. judging/perceiving personality categories. Indonesian Journal of Learning and Instruction, 1(2), 21-31.

Hoang, H. (2015). Metaphorical language in second language learners' essays: Products and processes (Unpublished doctoral dissertation). Victoria University of Wellington.

Hoang, H. (2019). Metaphorical language in second language learners' texts: Additional baggage of the writing journey? In E.Lindgren, \& K.Sullivan (Eds.), Observing writing (pp. 236-257). Brill.

Hoang, H., \& Boers, F. (2018). Gauging the association of EFL learners' writing proficiency and their use of metaphorical language. System, 74, 1-8.

Hulstijn, J. H. (2011). Language proficiency in native and nonnative speakers: An agenda for research and suggestions for second-language assessment. Language Assessment Quarterly, 8(3), 229-249.

Hussey, K., \& Katz, A. N. (2006). Metaphor production in online conversation: Gender and friendship status. Discourse Processes, 42(1), 75-98.

Iwaniec, J. (2019). Language learning motivation and gender: The case of Poland. International Journal of Applied Linguistics, 29(1), 130-143.

Jin, L. (2011). Second language acquisition of spatial metaphors in English and Chinese writings: Insights from native and learner language corpora (Unpublished doctoral dissertation). The University of Arizona, Arizona. 
Kapranov, O. (2017). The use of metonymy and metaphor in descriptive essays by intermediate and advanced EFL students. Linguistics beyond and within (LingBaW), 3(3), 87-101.

Kecskes, I. (2000). Conceptual fluency and the use of situation-bound utterances in L2. Links and Letters, 7, 145-161.

Kecskes, I., \& Papp, T. (2000). Foreign language and mother tongue. Lawrence Erlbaum.

Khajavy, G. H., Maclntyre, P. D., \& Hariri, J. (2020). A closer look at grit and language mindset as predictors of foreign language achievement. Studies in Second Language Acquisition, 43(2), 379-402. https://doi.org/10.1017/S027226312 0000480

Kövecses, Z. (2002). Metaphor. A practical introduction. Oxford University Press.

Kövecses, Z. (2017). Conceptual metaphor theory. In E. Semino \& Z. Demjén (Eds.), The Routledge handbook of metaphor and language (pp. 31-45). Routledge.

Lado, R. (1961). Lanquage testing. McGraw-Hill.

Lakoff, G., \& Johnson, M. (2003). Metaphors we live by. University of Chicago Press.

Littlemore, J., Krennmayr, T., Turner, J., \& Turner, S. (2014). An investigation into metaphor use at different levels of second language writing. Applied Linguistics, 35(2), 117-144.

Littlemore, J., \& Low, G. (2006). Figurative thinking and foreign language learning. Palgrave Macmillan.

Liu, S., \& Hsieh, C. Y. C. (2020). Developing metaphorical awareness and competence in Chinese as a foreign language through concept-based instruction. Foreign Language Annals, 53(3), 478-504.

MacArthur, F. (2010). Metaphorical competence in EFL: Where are we and where should we be going? A view from the language classroom. AllA Review, 23(1), 155-173.

Mahmud, M., \& Nur, S. (2018). Exploring students' learning strategies and gender differences in English language teaching. International Journal of Language Education, 2(1), 51-64.

Morris, L. (1998). Differences in men's and women's ESL writing at the junior college level: Consequences for research on feedback. Canadian Modern Language Review, 55(2), 219-238.

Nasab, M. S. H., \& Motlagh, S. F. P. (2017). Male and female students' narrative similarities and differences in the advance levels in line with advance organizers. Communication and Linguistics Studies. Special Issue: Applied Linguistics in Line With TEFL, 3(1), 8-13.

Norton, B., \& Pavlenko, A. (2004). Addressing gender in the ESL/EFL classroom. TESOL Quarterly, 38(3), 504-514.

Nourmohamadi, E. (2010). Conceptual metaphor and the acquisition of English metaphorical competence by Persian English majors: A cognitive linguistic approach (Unpublished doctoral dissertation). Allameh Tabataba'i University, Tehran, Iran.

Nyikos, M. (2008). Gender and good language learners. In C. Griffiths (Ed.), Lessons from good language learners (pp. 73-82). Cambridge University Press.

O'Reilly, D., \& Marsden, E. (2021a). Eliciting and measuring L2 metaphoric competence: Three decades on from Low (1988). Applied Linguistics, 42(1), 24-59.

O'Reilly, D., \& Marsden, E. (2021 b). Elicited metaphoric competence in a second language: A construct associated with vocabulary knowledge and general proficiency? International Review of Applied Linguistics in Language Teaching. https://doi.org/10.1515/iral-2020-0054

Pavlenko, A., \& Piller, I. (2001). New directions in the study of multilingualism, second language learning, and gender. In A. Pavlenko, A. Blackledge, I. Piller, \& M. Teutsch-Dwyer (Eds.), Multilingualism, second language learning, and gender (pp. 17-52). Mouton de Gruyter.

Pragglejaz Group. (2007). MIP: A method for identifying metaphorically used words in discourse. Metaphor and Symbol, $22(1), 1-39$.

Ross-Feldman, L. (2007). Interaction in the L2 classroom: Does gender influence learning opportunities? In A. Mackay (Ed.), Conversational interaction in second language acquisition: A collection of empirical studies (pp. 56-78). Oxford University Press.

Saneie Moghadam, M., \& Ghafar Samar, R. (2020). Metaphor in second language academic writing. Lanquage Awareness, 29(3), 255-271.

Schmenk, B. (2004). Language learning: A feminine domain? The role of stereotyping in constructing gendered learner identities. TESOL Quarterly, 38(3), 514-524.

Shakouri, N., Maftoon, P., \& Birjandi, P. (2016). On revisiting the sex differences in language acquisition: An etiological perspective. International Journal of English Linguistics, 4(6), 87-95.

Steen, G. J., Dorst, A. G., Herrmann, J. B., Kaal, A. A., Krennmayr, T., \& Pasma, T. (2010). A method for linguistic metaphor identification. From MIP to MIPVU (Converging Evidence in Language and Communication Research; No. 14). John Benjamins. http://www.benjamins.com/cgi-bin/t_bookview.cgi?bookid=CELCR\%2014.

Sunderland, J. (2004). Gender and language learning. In M. Byram (Ed.), Routledge encyclopedia of language teaching and learning (pp. 229-232). Routledge.

Trosborg, A. (1985). Metaphoric productions and preferences in second language learners. In W. Paprotte \& R. Dirven (Eds.), The ubiquity of metaphor (pp. 525-557). John Benjamins.

Ullman, M. T. (2005). A cognitive neuroscience perspective on second language acquisition: The declarative/procedural model. In C. Sanz (Ed.), Mind and context in adult second language acquisition: Methods, theory, and practice (pp. 141-178). Georgetown University Press.

$Y u, B$. (2018). The predicting roles of approaches to learning, L2 learning motivation, L2 learning strategies and L2 proficiency for learning outcomes: A comparison between Mainland and Hong Kong Chinese students. Educational Studies, 45(4), 520-532.

Zinken, J., \& Musolff, A. (2009). A discourse-centered perspective on metaphorical meaning and understanding. In A. Musolff \& J. Zinken (Eds.), Metaphor and discourse (pp. 1-8). Palgrave Macmillan.

\section{Publisher's Note}

Springer Nature remains neutral with regard to jurisdictional claims in published maps and institutional affiliations. 